УДК: $7.0725: 738.3$

DOI $10.21661 / \mathrm{r}-462331$

\title{
Н.Н. Ревенок
}

\section{ИСКУССТВОВЕДЧЕСКАЯ ЭКСПЕРТИЗА И АТРИБУЦИЯ МУЗЕЙНЫХ ФАРФОРО-ФАЯНСОВЫХ ИЗДЕЛИЙ}

Аннотация: в статье рассмотрены проблемы исследования музейного художественного фарфора и фаянса XIX - начала XX века в прочессе проведения искусствоведческой экспертизы, а также раскрыты основные критерии музейной атрибуции. Важной частью методологии экспертизы тонкокерамических изделий является разработка специальных методов их исследования в условиях современных лабораторий на приборах последнего поколения. Приведенные в статье результаты могут способствовать практическому применению предложенных методов при проведении искусствоведческой экспертизы произведений художественного фарфора-фаянса в музейной научно-исследовательской и реставраиионной работе.

Ключевые слова: экспертиза, атрибуция, реставрачия, музейная керамика, фарфор, фаянс.

\section{N.N. Revenok}

\section{ART EXPERTISE AND ATTRIBUTION OF MUSEUM PORCELAIN AND FAIENCE}

Abstract: the article considers problems of research of museum art porcelain and faience of the XIX - the beginning of the XX century in the process of carrying out fine art expertise and also reveals the main criteria of Museum attribution. An important part of the examination methodology of thin-ceramic products is the development of special methods for their study in the conditions of modern laboratories on the latestgeneration devices. The results presented in the article can contribute to the practical application of the proposed methods in conducting art criticism of art porcelain and faience in the museum research and restoration work. 
Keywords: examination, attribution, restoration, museum ceramics, porcelain, faience.

Актуальность исследования. Экспертиза и атрибуция культурных ценностей с целью идентификации фарфоровых и фаянсовых изделий на сегодня является актуальной проблемой. Предметы музейной художественной тонкой керамики в процессе фондовых сверок или при их реставрации иногда требуют отдельных исследований, уточнений и идентификации, что предусматривает ряд исследований: исторических, искусствоведческих, технико-технологических, a также ведения профессиональной научной документации, описание памятника и тому подобное. Экспертные исследования художественного фарфора, фаянса это процесс проведения сравнительного анализа характерных признаков предмета с тщательным описанием его формы, технологии изготовления, конструктивных особенностей, декоративного оформления, росписи на примере достоверно известных аналогов.

Анализ последних исследований и публикащуй. Проблемы атрибутивной идентификации культурных ценностей произведений искусства рассмотрены в трудах российских и украинских ученых. Так, известный искусствовед Б. Виппер, который изучал отдельные аспекты атрибуции, утверждал, что «атрибуция это пробный камень научно-исследовательской работы в музее и вместе с тем ее наиболее зрелый плод, ее венец» [6]. Сфера таких исследований оказалась весьма разнообразной и получила свое воплощение в ряде научных направлений.

Обычно музейная экспертиза нацелена на поиски имени и предоставлении достоверных сведений о памятнике. Более полную характеристику по проведению атрибуции предоставляют отдельные работы экспертов и искусствоведов В. Индутного [7; 8], В. Битаева [5], Б. Платонова [10], Т. Артюх [1; 2], А. Батутина [3] и др.

Особое значение в аспекте проблем научной экспертизы получили разработки эффективных направлений ее проведения В. Индутного. В частности, в книге «Оценка культурных ценностей» он справедливо утверждает, что «атрибуция памятников декоративно-прикладного искусства - это сложный процесс, 
в котором анализ формы, декора, цвета, материала, техники составляют взаимосвязанные элементы единого целого» [7, с. 51]. Автор предлагает принципиально новые решения проблем исследования памятников истории и культуры. По мнению В. Индутного, «для того чтобы получить правильный ответ, нужно обратиться к письменным источникам, в том числе и к архивным. Однако, одного знания литературы недостаточно, необходима постоянная работа с самим предметом, причем важно не только правильное эмоциональное осознание предмета, но и ощущение прикосновения к нему» [8, с. 51]. Мысли практика и освещенные им отдельные теоретические вопросы по научной атрибуции керамических изделий являются обоснованными и убедительными, но автор приходит к ряду выводов, которые не всегда подтверждаются фактическим материалом.

Современные исследователи Т. Артюх, Б. Платонов, В. Индутный, А. Минжулин сходятся во мнении, что искусствоведческая и атрибутивная работа с историческими памятниками является процессом последовательного накопления научных знаний о памятнике с документальным оформлением найденной информации о нем.

Осуществив теоретический анализ специальной литературы, можно утверждать, что проблема проведения атрибуции памятников истории и культуры затрагивали многие исследователи. Вместе с тем, целый ряд конкретных методологических вопросов, связанных с искусствоведческой экспертизой украинского фарфора и фаянса XIX - начала XX века остаются мало разработанными, например, проблемы исследования произведений музейной тонкой керамики техникотехнологического характера в ходе проведения их реставрации.

Цель статьи - осветить основные методы проведения музейной атрибутивной идентификации фарфоровых и фаянсовых изделий XIX - начала XX века в процессе искусствоведческих исследований и проведении научной реставрации.

Новизна научного исследования заключается в проведении исследования музейных художественных изделий фарфора-фаянса XIX - начала XX века, рассмотрения принципов их научной атрибуции, экспертизы, реставрации. 
Изложение основного материала. Атрибуция культурных ценностей (лат. Attributio - приписывание, присвоение, определение) - деятельность специалистов, направленная на исследование достоверности предметов, установление авторства, времени и места изготовления произведения. Основными признаками атрибуции является стилистический анализ, рассмотрение композиции и сюжета, иконографии, техники и технологии изготовления изделий. Кроме того, возможно использование лабораторных физико-химических анализов при помощи научных приборов таких как инфракрасный спектрометр немецкого производства «Vertex 70 FTI» с Фурье-преобразованием, РФА-спектрометр «ElvaXART», разработанный украинской компанией «Элватех» специально для изучения произведений искусства неразрушающим методом, благодаря чему можно без отбора проб определить состав неорганических составляющих исследуемого предмета с помощью аналитического программного обеспечения и т. д.

Особенностями экспертизы художественных фарфорофаянсовых изделий является выявление основных признаков, определение их исторического названия, назначения и бытования. Если предмет музейный, то устанавливают его связь с историческими фактами или персонами, расшифровывают надписи, клейма, маркировка и другие метки, определяют степень сохранности памятника и описывают его повреждения.

Визуально специалист может отличить европейский фарфор XIX века от Корецкого, Волокитинского или Барановского XIX века. Например, исследуя вопрос атрибуции художественного фарфора, известный русский искусствовед А. Салтыков дает такую формулировку: «Установление подлинности предмета занимает важное место в определении вещей. Причиной такой роли подлинности есть огромное количество подделок и фальсификатов, причем способы подделок керамических изделий в начале XX века настолько усовершенствовались, что проводить установление подлинности стало довольно трудно» [11, с. 266-267]. Следует отметить, что чаще всего фальсификаты встречаются среди редких цен- 
ных изделий тонкой керамики, поэтому для установления их подлинности эксперты нередко пользуются специальными каталогами с изображениями фарфорофаянсовых изделий разных эпох и каталогами аукционов.

Итак, характеризуя изделия тонкой керамики, определим главные особенности, которые могут подтвердить подлинность или опровергнуть их соответствие оригиналу:

1. Состояние сохранности предмета.

2. Время создания памятника, как важный критерий в проведении атрибуции, предоставляющий данные о соответствии стилистики предмета.

3. Уникальность и раритетность произведения фарфора-фаянса. Уникальность определяют по технике изготовления, сложности декорирования, росписи и другими факторами, раритетность - по минимальному его тиражированию.

4. Наличие клейм на изделии, проставленных различными способами и приемами - надглазурных, подглазурных, рельефных, в тесте и тому подобное.

Фарфоровые и фаянсовые художественные изделия описывают с учетом установленных общих идентичных элементов, а также отдельных специфических деталей.

Целью атрибутивной идентификации является сравнение подобных признаков исследуемых фарфоровых и фаянсовых изделий с признаками аналогичного произведения и установка, таким образом, или автора произведения, или предприятия, которое его выпустило.

Проблемы музейной атрибуции, экспертизы и реставрации неоднократно обсуждались на отечественных и международных научно-практических конференциях. В этом контексте весьма актуальной является публикация заведующего отделом фондов керамики Национального музея украинского народного искусства И. Бекетовой «Некоторые аспекты атрибуции произведений керамики (на примере собрания Музея украинского народного декоративного искусства)», где обозначены ряд дискуссионных моментов по определению стилистических особенностей изделий керамики: «Атрибуция включает анализ стилистических особенностей произведения. Понятие «стиль» означает исторически определенную 
совокупность образной системы художественных средств и способов». Кроме того, автор отмечает: «Стиль впитывает в себя национальные черты, связанные с конкретными условиями жизни и традициями народа» [4, с. 180]. И. Бекетова также указывает на то, что при исследовании стилистики памятники необходимо учитывать индивидуальную манеру автора: «Исследование стилистических особенностей помогает определить время и место бытования предмета. Определение стилистических черт произведения осуществляется на основе анализа его формы и декора. Музейные памятники далеко не всегда имеют яркие стилистические особенности. Определению стиля предмета мешает также существование имитаций, подражаний, копий» [4, с. 180]. Из сказанного выше можно сделать вывод, что атрибутивная работа с изделиями фарфора и фаянса предполагает, прежде всего, рассмотрение их стилистических особенностей, формы и декора.

Важно также отметить, что при разноплановом исследовании фарфорофаянсовых музейных предметов, их атрибуцию во многих случаях осуществляют по аналогам, а именно - подобным оригинальным произведениями, которые могут быть изготовлены из подобных материалов или иметь элементы аналогичной росписи или отдельных деталей декора (орнамента, завитков, отводок, обработки букетом отдельных частей поверхности изделия, наличия скульптурных элементов в отделке и т. д.).

В аспекте проблематики методов аналогий при проведении атрибуции произведений искусства привлекают внимание исследования В. Индутного в области оценивания антикварных предметов. Так, в своей работе «Оценка культурных ценностей» он отметил, что метод аналогий «заключается в том, чтобы найти признаки родства между экспортируемым предметом (аналогом) и уже проданными предметами (прототипами) и построить любое осмысленное не противоречащее высказывание. Этот метод предусматривает использование операций математической логики и логики предикатов, и черно-белое отображение результата в терминах «да» или «нет» [7, с. 30].

Далее исследователи В. Индутный и И. Бекетова сходятся во мнении, что «атрибуция культурных ценностей осуществляется с помощью аналитических, 
документальных, лабораторных (технико-технологических) методов исследования путем стилистического, сравнительного анализа и интерпретации» [7, с. 48].

Важным моментом в процессе проведения атрибуции и реставрации произведений искусства является обязательное ведение документации. «Документирование включает учет и информативность - введение в научный оборот и создание банка данных» [7, с. 48].

Особого внимания требуют замечания заведующего фондами Национального музея украинского народного декоративного искусства И. Бекетовой, которая утверждает, что каждый памятник связан с определенной средой, эпохой, конкретным событием и эту связь нужно установить: «Особенно важно выявить предметы, имеющие отношение к выдающимся деятелям или событиям, то есть предметы мемориальные. Данные о принадлежности памятника могут быть зафиксированы в письменных или изобразительных источниках» [4, с. 181].

Итак, искусствоведы, эксперты - теоретики и практики в исследовании памятников культуры руководствовались научным подходом, что позволяет объективно решать вопросы атрибуции предметов художественного фарфора и фаянса.

Важным фактором в проведении экспертизы и атрибуции произведений тонкой керамики - определении места изготовления памятника, авторства, времени создания - является исследование нанесенных, как правило, на обратную сторону различных клейм, марок, геральдических знаков, штампов, клейм в тесте, цифровых обозначений, надписей подглазурных, надглазурных, отметок золотом и тому подобное.

Следовательно, для эффективного проведения атрибуции нужно четко определить характерные признаки предмета, детально его осмотреть и выполнить:

- фотофиксацию предмета в разных ракурсах;

- провести замер изделия (измерить его высоту, ширину, длину, глубину, диаметр и т. д., указывая параметры в сантиметрах); 
- определить типологические признаки и принадлежность предмета к определенному времени и исследовать стилевые особенности орнаментальной росписи (растительной, геометрической, антропоморфной, зооморфной и др.) и отметить место ее расположения (на венчике, тулове, зеркале, по всему полю сосуда и т. д.);

- выяснить источник поступления информации о памятнике (экспедиция, дар, закупка и т. п.);

- исследовать исторические сведения о создании памятника, его функционирование, поступление в музей и тому подобное;

- установить постоянное место хранения, владельца памятника, автора;

- указать название предмета (если есть специальный термин), а также время создания;

- детально описать форму исследуемого предмета, материал, из которого он сделан, основу;

- определить технику, технологию изготовления и способ ее выполнения (ручная лепка, гончарный круг, шликерное литье, наличие ангобного покрытия, глазури с указанием цвета);

- определить орнамент (углубленный, рельефный, расписной) и роспись по цвету (монохромная, полихромная).

Поскольку виды отделки изделий тонкой керамики, в том числе с применением декоративных элементов, достаточно разнообразны, это требует их отдельной систематизации для профессионального составления искусствоведческих экспертных заключений и ведения реставрационной документации.

Произведения фарфора-фаянса является важным источником культурно-исторической информации, поэтому исследования памятников культуры, особенно музейных предметов, прежде всего, должны предусматривать расшифровку этих сведений.

В культурологических исследованиях широко применяется принцип структурно-функционального анализа, который имеет немаловажное значение в искусствоведческих исследованиях музейного фарфора-фаянса, так как каждый 
экспонат является носителем определенной информации исторического значения и обладает определенными функциями.

Целью структурно-функционального анализа художественных произведений тонкой керамики является описание их конструктивных особенностей, особенности фактуры материала и отображение подробной характеристики художественно-образного решения изучаемых предметов.

\section{Bblвodbl}

Искусствоведческая экспертиза и атрибуция музейных произведений тонкой керамики предоставляет возможность расширить знания об истории создания памятника, его бытовании, используя комплекс методов исследования: технико-технологические и специальные методы для исследования произведений фарфора и фаянса в условиях современных лабораторий; иконографически-иконологический метод для изучения изображений, декора, отдельных сюжетов и образов художественных произведений фарфора-фаянса; метод искусствоведческого анализа для обработки искусствоведческой, исторической, научной литературы по исследованию художественных изделий из фарфора и фаянса и другие.

В процессе атрибутивной идентификации и отождествления аналогий исследуемых фарфоровых и фаянсовых произведений с признаками бесспорно атрибутированого произведения можно установить авторство или предприятие, выпустившее продукцию. Детальное описание отражает понимание искусствоведом-экспертом или реставратором самой структуры памятника, его значение как информационного носителя определенной эпохи, события. Музейный экспонат в таком описании рассматривается как культурный феномен со своими определенными функциями.

Выявление специфических особенностей произведений фарфора и фаянса XIX - начала XX веков в ходе музейной атрибуции, экспертизы и реставрации является тем фундаментом, на котором строятся все остальные аспекты исследования, и открывает путь к практическому применению искусствоведческой экспертизы в процессе восстановления раритетных памятников. 


\section{Список литературы}

1. Артюх Т. М. Товарознавча експертиза ювелірних коштовностей: теорія та практика: Монографія / Т. М. Артюх. - К.: Київ. нац. торг.-економ. ун-т, 2005. $303 \mathrm{c}$.

2. Артюх Т.М. Експертиза дорогоцінних металів та дорогоцінного каміння: Навч. посіб. / Т.М. Артюх, Н.Б. Марчук, Л.В. Черняк. - К.: КНТЕУ, 2008. - 99 с.

3. Батутіна А.П. Експертиза товарів: Навч. посіб. / А.П. Батутіна, I.В. Смченко. - Львів: видавництво Львівської комерційної академії, 2010. $312 \mathrm{c}$.

4. Бекетова I.I. Деякі аспекти атрибуції творів кераміки (на прикладі збірки Музею українського народного декоративного мистецтва). Музейні колекції: історія, дослідження, атрибуція: збірник наукових праць / I I. Бекетова; за ред. М. Селівачова. - К.: ТОВ «ХІК», 2010. - С. 180-181.

5. Бітаєв В.А. Методичні засади експертного дослідження культурних цінностей: Навч.-метод. посіб. / В.А. Бітаєв, В.Д. Шульгіна, С.Ю. Шман. - К.: НАКKKiM, 2010. - 128 c.

6. Виппер Б.Р. Введение в историческое изучение искусства / Б.Р. Виппер. 2-е изд., испр. и доп. - М.: Изобразительное искусство, 1985. -288 с.

7. Індутний В.В. Оцінка культурних цінностей. - 2-ге вид. / В.В. Індутний, Е.В. Чернявська, С.М. Шкляр, С.М. Платонов та ін. - К.: АЯКС ПРІНТ, 2006. 608 с.: іл. В. Індутним. - С. 51.

8. Індутний В.В. Оцінка пам'яток культури / В.В. Індутний. - К.: СПД Моляр С.В., 2009. - С. 51.

Ревенок Наталья Николаевна - старший преподаватель кафедры реставрации Национальной академии изобразительного искусства и архитектуры, Киев, Украина.

Revenok Natalia Nikolaevna - senior lecturer of the Department of Restoration at the National Academy of Fine Arts and Architecture, Kiev, Ukraine. 